\title{
The Use of Edmodo to Improve the Writing Ability of English Department Students of State Polytechnic of Padang
}

\author{
DESI YULASTRI ${ }^{1}$, DHINI AULIA ${ }^{2}$, HENDRO SAPTOPRAMONO $^{3}$ \\ English Department, Politeknik Negeri Padang, West Sumatera, 2500, Indonesia \\ Email: desiyulastrilgmail.com, dhiniaulia.dalgmail.com, hspramonolyahoo.co.id
}

\begin{abstract}
This study aims to examine the usage of Edmodo for writing 1 subject for English Department students of State Polytechnic of Padang. The design of this research is experimental design; two classes became the experimental and control groups. There were 25 students in experimental group and 27 students in control group. Edmodo was used in experimental group while the control group was taught without using Edmodo. SPSS program was used to analyse the data. The result showed that the experimental group had improved significantly in their post test result. The paired samples statistics result showed that the mean of experiemental group post test was 70.32, while the control group post test was 63.94 . For the $t$ test result, the p value $(0.000)$ was less than 0.05 for the experimental group, which means that the null hypothesis was rejected. On the other hand, the $p$ value of the control group (0.06) was greater than 0.05 which means the null hypothesis was retained. From the statistic result, the study has proved that the use of Edmodo in writing class can improve students' writing ability. Therefore, the researchers suggest other lecturers to use the device. However, further study may need to involve larger population in order to elucidate further the efficacy of this application.
\end{abstract}

Keywords- Writing, Edmodo.

\section{INTRODUCTION}

English Department of State Polytechnic of Padang needs to prepare qualified graduates so that they can compete in the real working field. In order to prepare qualified graduates, the English Department has to design curriculum that meets the needs of students in achieving good skill of English. Having good skill in English means the students should have good skill in listening, reading, speaking and writing. However, in the real learning process, sometimes the students cannot maximally achieve these four skills especially writing skill. Through some observations and experiences in teaching writing for English students, it is found that there are hindrances for the students to increase their writing ability. The students do not have good grammar that can support them in writing class. Even though the students get grammar subject in the first and second semester, they still have difficulties in developing their writing ability. In fact, the writing subject is given in the same semester with grammar subject. This situation often creates problem in writing class. Since the students in writing 1 subject start the lesson by writing simple sentence, they should have known tenses and parts of speech, whereas in grammar 1 subject, parts of speech is taught as the first lesson. As a result, writing lecturers have to explain the grammar part before continuing with writing syllabus.

Furthermore, limitation in vocabulary is another obstacle for students in acquiring writing skill. As it is known that vocabulary takes important role in writing after grammar, developing and increasing awareness of the students in their vocabulary building is very essential. Reading various materials in English can be one of the ways in increasing students' vocabulary. Thus, the writing lecturer should also develop the students' skill in increasing their vocabulary. This will be a hard work, since most of the students in English Department have a poor vocabulary. It is because most of the students in English Department graduated from vocational 
high school, and from the researchers' observation, the students usually have low level in English while they were in high school.

In addition, the situation may get worse when the students need to write their internship report and final report in their last semester. With lack of writing ability, the students do not have good ability in writing the reports. Often, the lecturers have to teach them back about grammar lesson while supervising the report. This is, of course, time consuming and need lot of effort for both lecturers as supervisor and the students. If the students have good ability in writing, the process of writing the reports will not be a tough work for them.

To overcome the problems above, more teaching techniques and approaches are needed to increase the writing skill of the students. One of the ways to increase students' writing ability is by using EDMODO as academic network application. EDMODO works like Facebook but for academic purposes. By using EDMODO, lecturers can post assignments, quizzes, and all materials related to the subjects. For writing class, the lecturer may ask students to post their writing. With EDMODO, students have to post their work and give any comments to what the lecturers post since it will give them a mark. Since EDMODO is internet based, the students can access it anywhere as long as they get an internet connection. This is not a burden to them since in campus itself, in State Polytechnic of Padang, all students are given their own password to access internet. Moreover, most of the students have laptop, tablet and smartphone to connect with internet. In English Department itself, the students study in multimedia laboratory for writing subject, and all the computers are connected with the internet.

The present study will attempt to answer the hypotesis, whether the use of EDMODO can improve the writing ability of the English Dpeartment students of State Polytechnic of Padang.

\section{LITERATURE REVIEW}

\section{A. Writing}

In English as Foreign Language (EFL), writing skill is very pivotal for students to acquire beside listening, reading and speaking skills. Sokolik in Elorbany (2014) mentions that writing is a perceptual process that includes creating ideas, thinking of how to organize them and utter them so that others understand and respond to them. Similarly, Pulverness et al. in Utami (2014) explains that writing is one of productive skills which involves communicating a message by making signs, forming letters and words, and joining them into a series of sentences that link together to communicate that message. Hence, learning to write in EFL context will need rigorous efforts both for learners and teachers.

Furthermore, Hughey et al. in Hastomo (2015) mention that writing is often found as the most difficult skill among all of the English skills both as first and as the second language. In a similar vein, Murcia (2000) states that writing skill is often perceived as the most difficult skill to be mastered because it requires many aspects of language in its production such as organization, content, language use, mechanics and vocabulary. In writing exercise, students need to demonstrate their lexical range of words and also their grammatical points. They may need to know how to reveal their ideas clearly as they will transfer their thoughts to their readers.

In Indonesia, the students are likely to have less interest in writing subject, especially in the English writing subject. They only do writing when the teacher assigns them to do it as part of the classroom activities (Purnawarman et al.2016). The students seem have never written much either in their first language or second language (English) and thus they do not know how to construct ideas and formulate it in a sentence or paragraph (Harmer, 2007). There are many obstacles faced by the students in writing, for example, lack of grammar skill and critical thinking, and feedback from teachers and friends (Utami, 2014). Meanwhile, the higher students in university need to write their final project in the last year before they graduate. The situation may have created a burden for students in accomplishing their degree. At the end, the universities may have difficulty in increasing their graduates' qualification.

To overcome the above problems, several studies have been conducted to take advantages from Information and Communication Technology (ICT) devices to be implemented into the classroom activity. Dogoriti in Yulastri (2015) mentions that understanding the use and the value of ICT tools used in learning process can help 
educators revolutionize their approaches to teaching foreign languages and integrate technology in a meaningful way. One of the ICT devices is e-learning platforms. British Educational Communications and Technology Agency as cited in Lara (2013) defines e-learning platform as a broad range of ICT systems used to deliver and support learning. It has an integrated system with specific functions such as organizing, mapping, and delivering curriculum activities, and also supported by special space for teacher and students interaction which is done all by using ICT.

\section{B. Utilizing Technology in Teaching Writing}

Kessler, Bikowski, and Boggs (2012) mention that technology has influenced the writing process and practices in many ways. Furthermore, they argue that using technology for writing was seen as helping students see writing as fluid and dynamic and helping them focus more on the meaning in their papers early on as opposed to focusing excessively on form. Nowadays, many teachers have implemented blended learning course where the teachers and their students can have both online and face to face teaching (Lara, 2013). Through EDMODO, the teachers and their pupils may have not only classroom activity, but also virtual learning activity. By using this media, teachers can explain, deliver, and transfer the material for teaching writing.

Furthermore, teacher in using EDMODO as media should consider several things such as students' motivation and students' needs. Hastomo (2015) mentions that the teacher needs to explore and use the attractive media to motivate the students in learning activities. He further explains that the effective and efficient use of teaching media in learning process can be seen from the students' motivation upon the learning activities. Meanwhile, Bedenbaugh in Sattar (2015) explains that by providing learners with opportunities to learn in ways that satisfy their needs, they will eventually become more engaged in the learning process and in realizing their potential. However, Pennington in Kessler et al (2012) states that the degree of success of any application of word processing in an ESL setting will ultimately be determined by the nature of the users and the circumstances of use, rather than directly by the attributes of the medium. He furthermore notes that teachers using new technology must be patient in order to give students and instructors sufficient time to adapt to the technology and innovative teaching strategies that will arise.

\section{EDMODO: Definition and Usage}

EDMODO was created by Nic Borg and Jeff O'Hara in 2008 (www. EDMODO.com). The website is designed similar to Facebook so that students may not have difficulties in using it. Haygood et al. (2012) state that EDMODO is a private micro-blogging service which provides a free and secure learning platform. Furthermore, Cauley in Abadi et al. (2015) mentions that EDMODO is an educational website that takes the ideas of a social network and refines them and makes it appropriate for a classroom. Students and teachers can create their own account and have their own profile page. They also can join any communities and groups in it and share their opinions and knowledge in their groups (Ali, 2015). In other words, EDMODO is an academic social network where the teacher and the students can share each other of everything related to their academic activities.

There are several applications can be used in EDMODO which may be implemented into the classroom, such as reading, assignments, and paper studying. Not only that, in EDMODO, the teacher may use posting assignments, creating polls for student responses, embedding video clips, create learning groups, post a quiz for students to take, and create a calendar of events and assignments (Ulmer, 2013). For students, Ulmer (2013) mentions that they can turn in assignments or upload assignments for their teachers to be viewed and marked. Students may also post anything in their wall just like Facebook, however, the teachers should give a kind of rule of what the students can post and the words they use in post it. Since EDMODO is an academic site, it is important for the teacher to have their students familiarized with the academic words.

\section{Review of the Related Findings}

A research on the use of EDMODO for writing has been conducted previously by Purnawarman, Susilawati, and Sundayana (2016). They studied the use of EDMODO in teaching writing in a blended learning setting. The participants were 17 students of eleventh grade 
from private senior high school in Cimahi, West Java. Using qualitative method, the researchers investigated how EDMODO as a learning platform was implemented in teaching writing in its combination with Genre-based Approach, how EDMODO facilitated students' engagement, and how students perceived the use of EDMODO in teaching and learning activities. The findings of the research show that EDMODO is able to facilitate students' engagement cognitively during classroom sessions, and it is possible to integrate EDMODO into Genre-based Approach writing cycles (Purnawarman, Susilawati \& Sundayana, 2016).

Meanwhile, another study conducted by Hastomo (2016) investigated the effectiveness of EDMODO to teach writing viewed from students' motivation. The participants for this study were two classes of senior high school students from a senior high school in Bandar Lampung. The experimental design was used as methodology in which one class as control group and another one as experimental group. Two kinds of tests were given to both groups; writing test and motivation test. The findings of this research reveal that EDMODO is more effective to be used in teaching writing, and the students with high motivation have better writing skill than those having low motivation. The study also shows that there is an interaction between teaching media; EDMODO and students' motivation in teaching writing.

Based on these two studies above, the researcher team wants to investigate the use of EDMODO in higher education level, especially for English Department students in State Polytechnic of Padang. The findings of the research can give further explanation whether EDMODO can be beneficial to be used for higher level students. It also elucidates the students' preferences in using multimedia and how they integrate the knowledge they get during using EDMODO into their writing practices in the classroom.

\section{METHODOLOGY}

This research is classified into quasi experimental design. Creswell (2008) states that experiment design is used to establish possible cause and effect between independent and dependent variables. In this research, there were two variables; using EDMODO and writing ability. The researchers found out the cause and effect between these two variables. And there were two groups; experimental and control group which have been taken randomly from a population of this research.

Gay and Airisian (2009) state that the population is the entire group of interest to the researcher to which she or he would ideally like to generalize the study result. In this research, the population was the first year students of English Department in State Polytechnic of Padang who took writing 1 subject. Writing 1 subject is given at first semester for first year students, and followed by writing 2 in the next semester. There were two classes; class A and class B, in the first semester, academic year 2016-2017 and each class consists of 25 and 27 students respectively. These two classes were the subject of this research. Both classes were selected because the result of this research may be implemented to their further learning process.

The instrumentation that was used in this research is pre-test and post-test. These two tests were designed based on the syllabus of writing 1 subject. The lesson material in Writing 1 subject is included; sentence pattern 1, sentence pattern 2, paragraph structure, capitalization \& punctuation, unity and coherence.

The data was obtained from pre- test and post- test result. Both of the tests are in similar form and content. The pre-test was given prior to the treatment. The result of the pre-test score was calculated as the data. Next, the experimental group was given treatment, using EDMODO, and the control group without EDMODO. In the experimental group, lecturers could post lesson materials, related lesson materials, assignment, class discussion group in EDMODO, and the students could respond to their lecturers' comment and also give opinion to their friends' work. Meanwhile the control group does not use EDMODO for learning. Task based activity was conducted in this group; the lecturers explained the lesson and followed by giving several exercises and homework as well. After eight meetings, the post-test was given to both of the groups and the scores from pre-test and post-test were calculated by using SPSS program. 


\section{IV.RESULT AND DISCUSSION}

A. Result

The treatment given to the experimental group was EDMODO. For the first meeting, after the pre-test given, this group was taught on how to use EDMODO, and asked them to create student account in EDMODO. Since the Writing 1 subject was delivered in multimedia laboratory, all students could directly online from their computer. The duration for writing 1 subject was three hours per week and it run for eight weeks. There were 25 students in this group and taught by two lecturers. After all the students had their accounts, the lecturers asked them to join the Writing 1 class $1 \mathrm{~A}$ group in EDMODO.

For eight weeks, the lecturers would assign the students to post their comment, assignments, and find the lesson materials in EDMODO. The students were asked to check their EDMODO account every week so they can know all news posted by their classmates and lecturers. The lecturers used EDMODO as well in classroom to explain the lesson materials in the class. The comments and feedback from the students account were also shown in the classroom to highlight several errors or mistakes the students made in their comments. The outstanding students would also be honoured a badge so they aware that they get good achievement among their friends.

Meanwhile, students in control group received similar learning materials except EDMODO. There were 27 students in the group, and all of them received the lesson materials for 3 hours per week for about eight weeks. This group was taught by two lecturers and the class activity conducted in multimedia laboratory. The class activity referred to task based activity. The lecturers would explain about the subject and followed by several activities. The homework was given to the students and submitted to the lecturers.

For the experimental group, the lecturers started the activity by giving the pre test on the first week. The pre test items designed based on the writing 1 syllabus. There were 25 students in the experimental group. Eight meetings were conducted by using EDMODO in and outside the classroom. There were four times of discussion forum held in the group, two assignments, and two sharing materials. The students were asked to update their EDMODO status every week and give the respond to their friends' comments. Meanwhile, for control group, pre test were conducted on the first week, then the learning activity was delivered until week eight. All materials or hand out materials were given in the classroom.

On week nine, the post test was given and then the pre test and post test were calculated by using SPSS program.

After the data scored and analysed by SPSS program, it was obtained statistic result; paired samples statistics and paired samples test, as presented in Table III and Table IV.

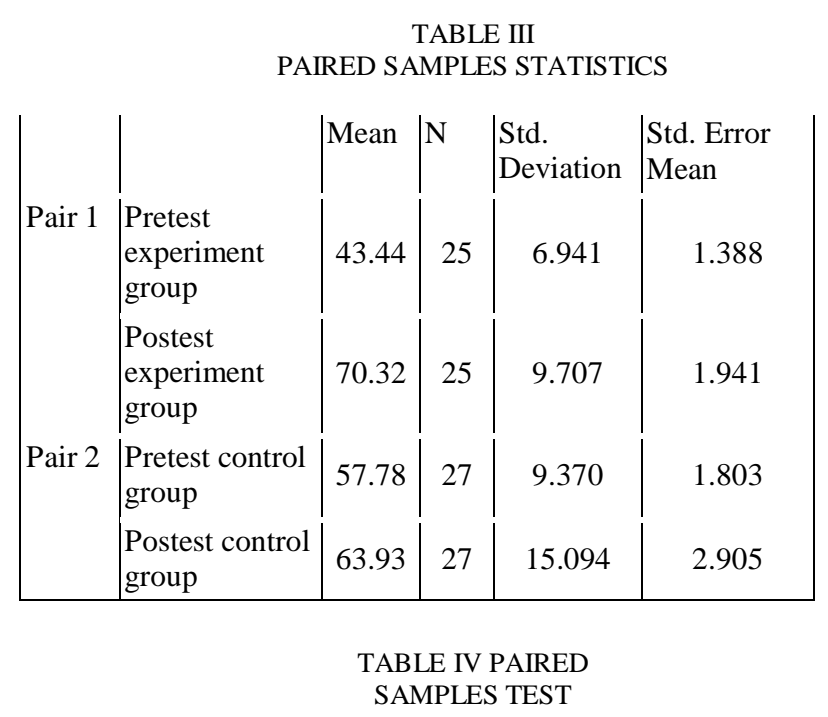

\begin{tabular}{|l|l|l|l|l|l|}
\hline & Mean & $\begin{array}{l}\text { Std } \\
\text { Deviation }\end{array}$ & $\mathrm{t}$ & $\mathrm{df}$ & $\begin{array}{l}\text { Sig.(2- } \\
\text { tailed) }\end{array}$ \\
\hline $\begin{array}{l}\text { Post test Pre test } \\
\text { Experimental } \\
\text { group }\end{array}$ & 26.880 & 10.569 & 12.717 & 24 & .000 \\
\hline $\begin{array}{l}\text { Post test Pre test } \\
\text { Control group }\end{array}$ & 6.148 & 16.257 & 1.965 & 26 & .060 \\
\hline
\end{tabular}

\section{B. Discussion}

The two groups had demontrated the progress during the research. However, the experimental group showed a significant result with the mean of pre test 43.44 and post test 70.32 compared with the mean of control group which was only 57.78 on the pre test then became 63.93 on the post test (Table 3). In addition, the experimental group had lower mean than the control group. It can be assumed that the first group had relatively poor ability in writing than the second group.

Furthermore, the statistic result as presented in table 4 for the $t$ - test showed that the experimental group had a $\mathrm{t}(24)=12.717$, and the 
$\mathrm{p}$ value is less than $0.05 \quad(\mathrm{p}=0.000)$ which means that there was significant improvement of the writing ability in this group after learning by using EDMODO in and outside the classroom. Whereas for the control group, the $t(26)=1.965$, with the $p$ value greater than $0.05(\mathrm{p}=0.06)$ means that there was no significant progress in their writing ability. Thus, since the $\mathrm{p}$ value of the experimental group was less than 0.05 so that the null hypothesis in this study was rejected. From the above explanation, it can be said that this research gives a proof that the use of EDMODO can improve the writing ability of the students in English Department of State Polytechnic of Padang.

\section{CONCLUSION AND SUGGESTION}

\section{A. Conclusion}

Through this study, it can be found that the experimental group had better improvement in their writing ability after EDMODO was given. In control group, the result of their post test did not show the significant progress. In other word, the use of EDMODO has given positive effect for the students writing skill. Moreover, the class activity through EDMODO such as forum discussion, sharing materials, and assignments have given students more chance to write more. In addition, from the t-test result, the mean score of pre test for control group was higher than those for experimental group. The researcher may conclude that eventhough the control group had better ability in writing, the post test result did not show better progress if it compared with the experimental group post test result.

\section{B. Suggestion}

Based on the result of this study, the researchers give several suggestions below:

1. The technology may be utilized in teaching, especially in teaching writing.

2. One of the technology devices that can be used for teaching is EDMODO.
3. For other lecturers and researchers, it is suggested to study the usage of EDMODO for other subjects.

4. Lecturers who want to use EDMODO for their teaching activity should have spare time outside the classroom to connect with their students through EDMODO.

\section{REFERENCES}

[1] Abadi, B. B. S., Ahmadi, S. D., \& Mehrdad, A. G. (2015). The Effect of Edmodo on EFL learners' writing performance. International Journal of Educational Investigations, Vol.2, No.2, pp. 88-97.

[2] Ali, Z. (2015). A Case study of tertiary students' experiences using Edmodo in language learning. International Journal of Language Education and Applied Lingustics, Vol.2, pp.39-48.

[3] Creswell, J. W. (2008). Educational research: Planning, conducting, and evaluating quantitative and qualitative research. New Jersey: Pearson Merill Prentice Hall.

[4] Elorbany, M. I. (2014). A Blended language learning model: Adolescent learners' attitudes towards it and its effectiveness in the teaching and learning of L2 writing. (Unpublished Dissertation). Retrieved

http://bspace.buid.ac.ae/bitstream/1234/667/1/120076.pdf

[5] Gay, L, R. (2009). Educational research competencies for analysis and applications. New Jersey: Pearson Education Ltd.

[6] Harmer, J. (2007). The Practice of English language teaching. United Kingdom: Pearson Education Limited.

[7] Hastomo, T. (2016). The Effectiveness of Edmodo to teach writing viewed from students' motivation. Proceeding ICTTE FKIP UNS, Vol.1, No.1, pp.580-585.

[8] Haygood, E., Garner, R., \& Johnson, S. (2012). Blended learning: Using web $2.0 \mathrm{~S}$ to enhance classroom instruction, Interlink Alliance retrieved from http://www.cehs.ohio.edu/

[9] Kessler, G., Bikowski, D., \& Boggs, J. (2012). Collaborative writing among second language learners in academic web-based projects. Language Learning \& Technology, Vol. 16, No.1, pp.91-109.

[10] Lara, V. D. (2013). The Improvement of writing based on a genre approach through the use of an e-learning platform. (Unpublished Dissertation). Retrieved from http://cdigital.uv.mx/bitstream/123456789/35143/1/duranlaravanesa. pdf.

[11] Murcia, C. M \& Olshtein, E. (2000). Discourse and context in language teaching. New York: Cambridge University Press.

[12] Purnawarman, P., Susilawati, \& Sundayana, W. (2016). The Use of Edmodo in teaching writing in a blended learning setting. Indonesian Journal of Applied Linguistics, Vol.5 No.2, pp. 242-252.

[13] Sattar, Sanyat. (2015). Learning via blogging: The ESL/EFL perspective. Journal on Education, Vol.3, No.1, pp.7-12.

[14] Ulmer, J. (2013). Edmodo: Understanding innovation. Retrieved from http://prezi.com/rrc-lmutkxxz/edmodo-understandinginnovation/.

[15] Utami, A. B. (2014). English education in EFL context: Integrated approach for collaborative writing in the university level. Journal of Education, Vol.7, No.1,pp.40-50.

[16] www.edmodo.com

[17] Yulastri, D. (2015). Building students' writing skill by using edmodo. Journal Polingua,Vol.4, No.2, pp.47-51. 